\title{
On the Open and Closed Space of Public Discourse
}

\author{
LeIF DAHLBERG
}

\begin{abstract}
The subject of this article is to investigate the notion and status of public discourse in contemporary media. The article opens with a reading of the trope the 'open' (das Offene) in Rainer Maria Rilke's eighth Duineser Elegie and then discusses the meanings given to openess and public (Öffentlich, Öffentlichkeit) in the academic discourses of law, philosophy, political theory, and sociology. However, the principal focus of the article is on the artistic and political interventions by two Austrian artists, Otto Mittmannsgruber and Martin Strauß, made in commercialized public spaces in Austria and Germany during the years 1995-2004. Their artistic works directly address issues of power and public discourse, and effect both a questioning of unilinear mass media communication and a politicization of commercialized public space. In the article it is argued that the interventions of Mittmannsgruber and Strauß in commercial mass media make strikingly visible the simultaneously open and closed nature of contemporary public discourse.
\end{abstract}

Key Words: public space, public discourse, advertising, ad-busting, media art

\section{Introduction}

This article discusses the notion of and conditions for public discourse in contemporary European society. It concerns itself in particular with public discourse in advertisement space, which simultaneously constitutes an open and closed discursive space. Advertisement space is used for planned communication (product and corporate advertisement, social information or political propaganda) in which the aim of the sender is to create strong public recognition of product or brand identity. The central focus of the article, however, is on the artistic and political interventions in commercialized public spaces by two Austrian artists, Otto Mittmannsgruber and Martin Strauß, interventions which are used as prisms to examine the nature of public discourse today. During the years 1995-2004, the artists executed a series of artistic projects in public spaces in Austria and Germany, primarily on billboards used for advertisements. Through a playful and ironic use of the rhetoric of visual language of advertisements, the artists achieve an allegorizing deconstruction and effacement of the iconographic strategies of corporate product identity. In this way, Mittmannsgruber and Strauß open our eyes for the conditions for and the meaning of public discourse in public spaces of today. 
Much has been written about the public sphere, public spaces or public discourse and I make no claim to say anything substantially new, but perhaps this article may shed some new light on public discourse in public spaces and how it shapes this space as part of the public sphere. ${ }^{1}$

\title{
The Open and Closed (Rilke)
}

In his eighth Duineser Elegie, Rainer Maria Rilke depicts how the animal relates to the world as open ("Mit allen Augen sieht die Kreatur / das Offene"), while the eyes of man are "as turned around" (wie umgekehrt) and surrounded by traps that prevent free sight (Rilke 1991: 470-472). ${ }^{2}$ This conversion, or "turning about", is forced upon us already as children, turning us away from the open and towards the already interpreted. According to Rilke, in the face of the animal, in the look of the animal, we can see freedom from the closed, pre-interpreted world, an unawareness of death that contains an openness towards God. The regard organizes space, but space and time also organizes the regard. In the poem Rilke develops this theme in different ways and describes how man is unable to see "nowhere without nothing" (Nirgends ohne Nicht) but only sees world. We know nothingness only as death. The unaffected seeing we can only perceive in the animal, never experience ourselves. This condition for our perception also describes a historical itinerary, where civilized man with his acquired knowledge has lost the animal's pure seeing; it describes a fall from innocence and grace.

But in some animals, Rilke writes, "in the vigilant warm animal" (in dem wachsam warmen Tier), one can perceive the burden of an inexpressible sorrow. However, it is not a consciousness of death, but a "faint memory" (Erinnerung) that what we long for once has been "closer, truer and enclosed itself around us infinitely caring" (näher gewesen, treuer und sein Anschluß / unendlich zärtlich). It is the memory in the warm blooded animal of an existence before birth; while after we are born, expelled from the womb, "everything is distance" (ist alles Abstand). There is in these animals a kind of historical consciousness of coming after, of having fallen from a previous state of grace. The poet then exclaims:

\author{
O Seligkeit der kleinen Kreatur - \\ Die immer bleibt in Schooße, der sie austrug; \\ o Glück der Mücke, die noch innen hüpft, \\ selbst wenn sie Hochzeit hat; denn Schooß ist Alles.
}

For these smallest creatures there is no difference between the unborn condition and life in the world. For them there is no difference between the closed, safe being, and the open, unprotected world. They are always at home. In their world there is no division between home and away, between private and public. But for civilized man, the distinction between private and public is like an open wound.

Rilke's poem describes man's condition as a cultural being as created by drawing up a series of boundaries with subsequent separations, spatial and temporal. According to Rilke these borders and distances exist as much within man as outside. Yet this activity of organizing the world in ourselves is unable to create a stable order in the world. Rilke writes that we order the world in ourselves, but only in order to see it fall apart ("Wir ordnens. Es zerfällt"); and then finally we fall apart ourselves: "Wir ordnens wieder und zerfallen selbst." This endless toiling refers both to individual human beings 
and to man in general, what concerns the individual is also true of how man as a social being structures the world.

The conjunction of the individual and the general, of part and whole, constitutes a rhetorical figure (metonomy) that contains an internal division of the kind Rilke speaks. Man is always separated from mankind by his own individuality. As is suggested in Rilke's poem, the individuating process is initiated already in childhood, but it is only as adults that we fully learn to make proper and responsible distinctions between ourselves and others, between private and public. It is therefore fitting that in most societies the transition from child to adult is marked by rites of passage (Gennep 1909: 93163). In western societies one graduates from secondary school, gets a job or goes to university and moves into an apartment of one's own. This transition into the adult world does not necessarily designate a loss of the protected haven of the family, but signals an entry into the political sphere.

One of the most important borders that civilized man has drawn is precisely the one between what is one's own and what is shared, between private and public, what the ancient Greeks called oikos and polis. What is contained in this distinction? The English and French term public (publique) has a double etymology which is quite telling: the word comes in part from the Latin poplicus (of the people), in part from pubes (adult). It is as an adult one is given entry to what is shared, the common sphere, and to matters of state, the political sphere. But not all public places are political, and not all political spheres are public. In the words of Hannah Arendt: "Wherever people gather together, it is potentially there, but only potentially, not necessarily and not forever." (Arendt 1958: 199) The public realm is also delimited by areas that are not of common concern, but are considered private (from Latin privatus, "withdrawn from public life"), as well as such matters of state that are closed from the public. It follows that what takes place in public, happens in the open (compare the German das Offene, heard in Öffentlich, Öffentlichkeit): everything that appears in public can be seen and heard by everybody (Arendt 1958: 50). ${ }^{3}$ This shared and open public realm is in turn a necessary condition for making sound political judgements in a democratic society.

Indeed, in modern western societies there is a strong connexion between the view of democracy as a theory of accountability and responsivenes in decision-making process and theories of the public sphere as a form of public communication that will facilitate this process. But what qualities should the public sphere have in order to nurture and sustain a vigorous and democratic public life? Who should participate and on what conditions? What should be the forms of public discourse and who should decide the issues to be discussed? How should the actors communicate with each other? And what is the desired outcome of political debate in the public sphere?

In order to get a preliminary idea of the different (and differing) meanings of the notion of the public it may be helpful to set up a matrix over separate aspects of public space and political discourse: 


\begin{tabular}{|l|l|l|l|}
\hline & Concrete spaces & $\begin{array}{l}\text { Concrete } \\
\text { figurative spaces }\end{array}$ & Abstract spaces \\
\hline $\begin{array}{l}\text { Political } \\
\text { discourse }\end{array}$ & $\begin{array}{l}\text { Council, assembly } \\
\text { rooms, meeting } \\
\text { places, etc }\end{array}$ & $\begin{array}{l}\text { Editorial columns, } \\
\text { political articles; } \\
\text { TV-debates, etc. }\end{array}$ & The public sphere \\
\hline $\begin{array}{l}\text { Unpolitical } \\
\text { discourse }\end{array}$ & $\begin{array}{l}\text { Public places, } \\
\text { public spaces }\end{array}$ & $\begin{array}{l}\text { News, articles \& } \\
\text { TV-programmes on } \\
\text { sport, fashion, music, } \\
\text { culture; chat pages }\end{array}$ & The public space \\
\hline
\end{tabular}

The distinct spatial order of the schema is in several ways misleading. There does not exist an agreed nomenclature of different public spaces and the discourses that occur there. However, it is quite common that one by public places mean concrete and (primarily) unpolitical spaces; by the term public space is meant an abstract and (primarily) unpolitical space; and by (the) public sphere is meant an abstract and political space. Apart from disagreeing about whether this corresponds with ordinary usage of the terms, one may argue against these distinctions that the division between the political and unpolitical cannot be made (so) univocal, either in theory or in practice. This is quite correct. It can also be noted that depending on how one draws the line - between the political and the unpolitical - the public sphere will look quite different. There are furthermore several reasons why such a distinction perhaps should not be made at all (the public is always political) and that the border to the private also always (already) is political (Foucault 2001; Foucault 1997; Foucault 2000; Smith 1999). It should also be noted that just as there are different kinds of public spaces and public discourses, the private realm has many different faces.

In her book The Human Condition (1958), Hannah Arendt discusses at some length the meaning of the public realm as an open and shared space, in particular as regards the classical Greek city state (Arendt 1958: 50-78 et passim). In her view, a true public realm is only possible with a limited number of citizens, the ideal found in the Greek city state. When the number of people increases, there develops "an almost irresistible inclination toward despotism, be this the despotism of a person or of majority rule [...]." (Arendt 1958: 43) In Arendt's view, the classical public realm was a space where the citizen could appear as an individual, hence it was a scene of distinction (Arendt 1958: 41, 56, 58). In contrast to the private realm, which was characterized by inequality, necessity, labor, and futility, the public realm was considered a space of equality, freedom, and permanence, and it was in the public realm that the individual could earn recognition and honour (Arendt 1958: 32, 73). Although not always made explicit in the discussion, this view of the classical public sphere often forms the ideal for the modern public sphere. In other words, when applied to the modern age, the public realm is frequently a figurative notion. Arendt herself makes this clear when she writes that with the rise of the nation state there emerges a new realm, which is neither private nor public, that she calls the social realm (Arendt 1958: 28, 257). For Arendt, the indistinction of private and public constitutes a threat to a well functioning public sphere, and hence to democracy (Arendt 1950). In contradistinction to this view, there are those who argue that the insistence on separating the private and public realms leads to excluding groups (or interests) from the public realm. For instance, Seyla Benhabib has argued that the public sphere should not be understood agonistically as a space of competition for recognition and immortality among a political elite. Instead, it should be viewed "democratically as the creation of procedures whereby those affected by general social norms and collective political decision can have 
a say in their formulation, stipulation, and adoption." (Benhabib 1992: 87) Furthermore, Benhabib argues for the proliferation of several, autonomous public spheres, which would ensure that radically different interests may articulate and voice their views.

The kind of public space that Jürgen Habermas calls the bourgeois public sphere (bürgerliche Öffentlichkeit) is characterized exactly by being separate from the political power, but at the same time constituting an arena where one may discuss and criticize political power, and where political opinions can take shape (Habermas 1962: 1426). The bourgeois public sphere, as conceived by Habermas, constitutes a middle-space between the private realm and the state, a space that has developed out of the private sphere (Habermas 1962: 27-43). In analogy with Rilke's poem one can say that the bourgeois public sphere has been borne by the private sphere, and that it looks back to it as at a forlorn place. The idea is that the public sphere should simultaneously be open and sheltered. Hence according to Habermas this public sphere should still be conceived as "private" in relation to the state, and he draws the following diagram over the bourgeois public sphere in the eighteenth century (Habermas 1962: 30):

\begin{tabular}{|l|l|l|}
\hline \multicolumn{2}{|l|}{ Private realm } & Sphere of Public Authority \\
\hline $\begin{array}{l}\text { Civil society (realm of } \\
\text { commodity exchange and } \\
\text { social labour) }\end{array}$ & $\begin{array}{l}\text { Public sphere in the } \\
\text { political realm } \\
\text { Public sphere in the world } \\
\text { of letter (clubs, press) } \\
\text { (Market of culture } \\
\text { Conjugal family's internal } \\
\text { space (bourgeois } \\
\text { intellectuals) }\end{array}$ & Court (courtly-noble society) \\
\hline
\end{tabular}

In Habermas scheme, the bourgeois public sphere appears as a dialectical middle term, growing out of the historical opposition between civil society and political power, between the private realm and the state (Habermas 1962: 141). As such, it will be dependent on a precarious balance of power between civil society and the state (Habermas 1962: 181).

Just as the public sphere in the classical city state was historically determined, the bourgeois public sphere as described by Habermas is said to emerge in specific historical and political circumstances, most important is the social rise of the bourgeoisie and the development of an independent press. Although Habermas' thesis about the bourgeois public sphere has been very influential, there has been levelled serious criticism that his description of the period is both tendentious and idealistic. On the one hand, he is said to have failed to account for social groupings not belonging to the bourgeoisie, who have oppositional interests to them (sometimes termed counterpublic spheres); he has not taken into account that women not only were excluded from the public sphere, but that the bourgeois public sphere was characterized by rational discussion and universality, qualities which at the time were considered essentially male; and there existed a number of other journals that had different agendas than the ones Habermas put emphasis on (Thompson 1968; Fraser 1992; Carey 1995; Thompson 1995: 71-75). On the other hand, it has been argued that Habermas idealises the forms of the intellectual and political discussion: far from being an arena for open dialogue among equals where the shared objective is a search for truth and the common good, the debates were conducted by a social and economic elite and ruled by conflicting interests and partisan politics (Schudson 1997). Whereas Habermas in later works has conceded the first series of criticisms, he has maintained that the notion of the public sphere as an arena for dialogue 
and reason constitutes a historical ideal, though not necessarily an existing reality (Habermas 1996: 329-387 et passim; Dahlberg 2005).

The views and theories of the public sphere presented so far have all put emphasis on active participation of the citizens, although in different degrees. The most inclusive theories are those that argue for a plurality of public spheres and a floating distinction between private and public. In their view, no space is really outside the political, and hence the private realm can only mean exclusion from the public sphere and deprivation of power. According to this view, the objective is to expand the public sphere and to avoid exclusion. In the view of the public sphere presented by Arendt, on the other hand, which in many ways is similar to conceptions of direct democracy found in JeanJacques Rousseau, the decisive role of the public sphere is to empower the individual and make him or her an active participant in the decision-making process. In contrast to this view, in the theory of public sphere presented by Habermas, often called a discursive theory of democracy, the principal role of the public sphere is to be a space for public communication and dialogue governed by mutual respect between the participants. Although in Habermas' theory the active participation of the public is viewed as positive, it is not considered as an end in itself. Instead, the principal objective is public dialogue and deliberation.

One can discern yet another theory of the public sphere, found in classical liberal theory and with roots in the works of Edmund Burke and John Stuart Mill (Burke 1790; Mill 1861). In this theory, sometimes termed representative liberal theory, the participation of the citizens in the public sphere should be limited and largely indirect. Instead of direct participation, the discussion should be carried out by representatives, either in the form of interest groups or (preferably) political parties. The main function of the public sphere is to provide the citizens with enough information about the political parties so that they can choose intelligently among them (Schumpeter 1942; Downs 1957; Kornhauser 1960). The public sphere should therefore be a free market place of ideas governed by expertise, transparency, proportionality, and with the ultimate goal of reaching sound decisions. This conception of the public sphere is strongly rejected by Habermas and other representatives of discursive theory. In their view, political communication in representative liberal theory is reduced to the strategic struggle between parties and interest groups for the attention and support of an audience of self-seeking and divided private individuals (Habermas 1996: 362).

These four different models or traditions of the public sphere are defined in relation to each other, and the differences between them are to some extent a matter of emphasis. It is also important to keep in mind that private and public designate figurative spaces and do not refer to natural categories. Instead they describe culturally constructed phenomena and are used to construct and legitimize relations of power in society.

\section{Transformations (Commerce \& ICT)}

In contemporary society, public space and public discourse - whatever more precisely is designated by these terms - are going through radical transformations. These changes are not in the first place related to the decline or refeudalization of the public sphere (due to social and political changes) that have been discussed by Habermas and others (Habermas 1962: 195; Boggs 1997). The transformations are instead related on the one hand to a massive commercialization of public places and of the public space; on the other hand to the use of new digital information- and communication technologies (ICT) 
(Castells 2001). The former is apparent in several ways. While merchants since ancient times have gathered in public places to conduct their business, the trend in the last several decades have been to create their own trading places, shopping malls and shopping clubs (Leong 2001; Chung 2001). In some suburban areas it seems as if shopping has become the only way one experiences public life (Leong 2001: 134, 153). ${ }^{4}$ Another striking form of commercialization of public space is that of advertisements, which apart from political propaganda in times of election - are the only media voices in these environments. Although advertising has been around for a while, it was only in the late nineteenth century that it became an industry and began to be a real presence in the urban landscape (Danesi 2002: 181-183). ${ }^{5}$ In contemporary urban and suburban society, advertising clutters public space. Apart from print and electronic media (the press, radio, television, Internet), it is found in the subway, on buses and bus stops, on billboards and covering house facades. But as if this was not enough, the latest trend in marketing is to saturate every conceivable space with commercial messages: on fruits and in lunch bags, in the bottom of beer glasses, in bathrooms and on the display of ATMs, in text books and schools, on the concrete of sidewalks and the sand on the beaches (Berger 2001: 430-446; Klein 2000: 87-105; Gunter \& Inaba 2001). We live in a world of ubiquitous advertising.

The radical transformation of modern ICT means that public institutions communicate with citizens in different ways than before, just as citizens may communicate with the authorities in new ways. This involves challenges and leads to changes in the meaning of the public sphere, both spatially and discursively. One example is what in Sweden is called 24 hour authority (24-timmarsmyndigheten), which provides social information around the clock and serves as a portal for many public services (Proposition 1997/98:136). In many other contexts new ICT has lead to changes: with the Internet ordinary citizens have been provided with the possibility to communicate with other people in ways that previously were reserved for those who enjoyed considerable political, economic or cultural capital. As an example of this can be mentioned diary-writing on the Internet, so called blogs, which simultaneously is an intimate, private form of communication and is publicly available for anybody who has access to Internet. The communicative practices made possible with new ICT will lead to changes in the distinction between private and public even more radical than what we saw in the $1950 \mathrm{~s}$ and 1960s with the introduction of broadcast television. ${ }^{6}$ There are even voices that argue that the distinction between private and public may dissolve altogether (Camp \& Chien 2000). ${ }^{7}$ Furthermore, the multiplication of media channels leads to a fragmentation of the media as a single or unified public sphere, which would affect its role in democratic society.

There will be reason to come back to these issues in other contexts. However, in the remainder of this article I want to discuss the significance of the fact that mediated discourse in (physical) public places in contemporary western society to a large extent has been monopolized by an advertising monologue that shuts out other public discourses, and that this advertising monologue closes in the mediated discourse in public spaces in a persuasion and marketing discourse whose primary - if not exclusive - objective is to speak to us as consumers. In this sense one may speak of public discourse in these environments as being closed to the public, but in extension also that this advertising monologue threatens to transform these public spaces to a closed space. ${ }^{8}$ What is the significance of this figurative transformation of the open public space into a closed space? What are the effects on public discourse in general? Would it be correct to as- 
sume, with Arendt, that the banishment of citizens from the public realm is a way to do away with plurality in human society (Arendt 1958: 220-221). In order to explore these and related questions I will now look at some artistic interventions in commercialized public space made by the Austrian artists Otto Mittmannsgruber and Martin Strauß.

\section{Media Art \& Public Art (Mittmannsgruber and Strauß)}

During the years 1995-2004, Mittmannsgruber and Strauß executed a series of artistic projects in commercialized public spaces in Austria and Germany, primarily on billboards used for advertising (in streets, at bus stops, house facades). These public media spaces are used for planned communication (primarily product and company advertising, but also social information and under election periods for political propaganda) where the objective of the sender is to create a strong consciousness in the receiver of product and brand identity. Through a playful and ironic use of the rhetoric of visual language in advertising, Mittmannsgruber and Strauß have achieved an allegorizing deconstruction and defacement/effacement of the iconographic strategies for product and company identity.

In the years 1995 and 1999, they carried out a project with the title "Monolog des Vertrauens" (Monologue of trust) with 2200 posters and 29 different subjects put up on billboards in Vienna, Graz, Linz and Innsbruck (in 1995), and in Berlin, Hamburg, Munich, Frankfurt and Essen (in 1999) (Mittmannsgruber \& Strauß 2004: 14-24). ${ }^{9}$ Each advertising poster was reduced solely to the name of the company. But the company name was also stripped of its typical form. In this way the visual image of the company's logotype was negated, and with it the formal identifications of the companies that had been established through years of brand marketing. Instead, the company names were made part of a common communicative structure and were set, one and all, in the same collective print scheme. As Mittmannsgruber and Strauß themselves note, this made for an aesthetic uniformity of representation otherwise never seen in this context:

The foregrounds of advertising posters always present the rival slogans of the respective companies - each one aimed at emphasizing the uniqueness of its advertising message, both in its verbal text and in its visual image. In our project these aesthetic constructs were dismantled and, in one double step, completely eradicated. (Mittmannsgruber \& Strauß 2004: 22)

In this way Mittmannsgruber and Strauß turn the rhetoric of advertising upside-down and inside out. In order to understand the "advertisements" the viewer is forced to actually read the names (perhaps even the letters) and then for him or herself make the connexion to the company and its product. Hereby the relation between name and image (the logotype) is being estranged and disautomatised, but it also effects a rhetorical effacement of company identity: there is no longer a purely visual difference between Benetton, Esso, Saeco, Adidas, and Honda. This heretic approach to advertising is radically new, which perhaps is one reason why the participating companies not only were willing to subject themselves (and their brands) to this kind of treatment, but also to foot the bill (Ullrich 2004: 124). As will be discussed later, it may also be considered trendy to be associated with alternative social movements such as culture jamming and ad-busting.

In a similar way Mittmannsgruber and Strauß effaced the differences between company identities in a project with the title "Shokomonolog" (Chocolate monologue). This project was carried out in Vienna in 2003 with 1100 posters and 11 different subjects 
(Mittmannsgruber \& Strauß 2004: 94-104). In contrast to "Monolog des Vertrauens", the companies were here allowed to retain their logotypes, but instead are assimilated by "selling" the same product: chocolate bars. It is suggestive to read the image of the chocolate bar as a metaphor for the vain promises made by advertisements: by buying chocolate you will be happier, more attractive and in general more satisfied with life. But of course eating chocolate will do none of these things, if anything it will make you thirsty. If the primary objective of advertising is to create desire for something the product itself never can provide, then Mittmannsgruber and Strauß's chocolate monologue constitutes a visual allegorization of this kind of advertising rhetoric.

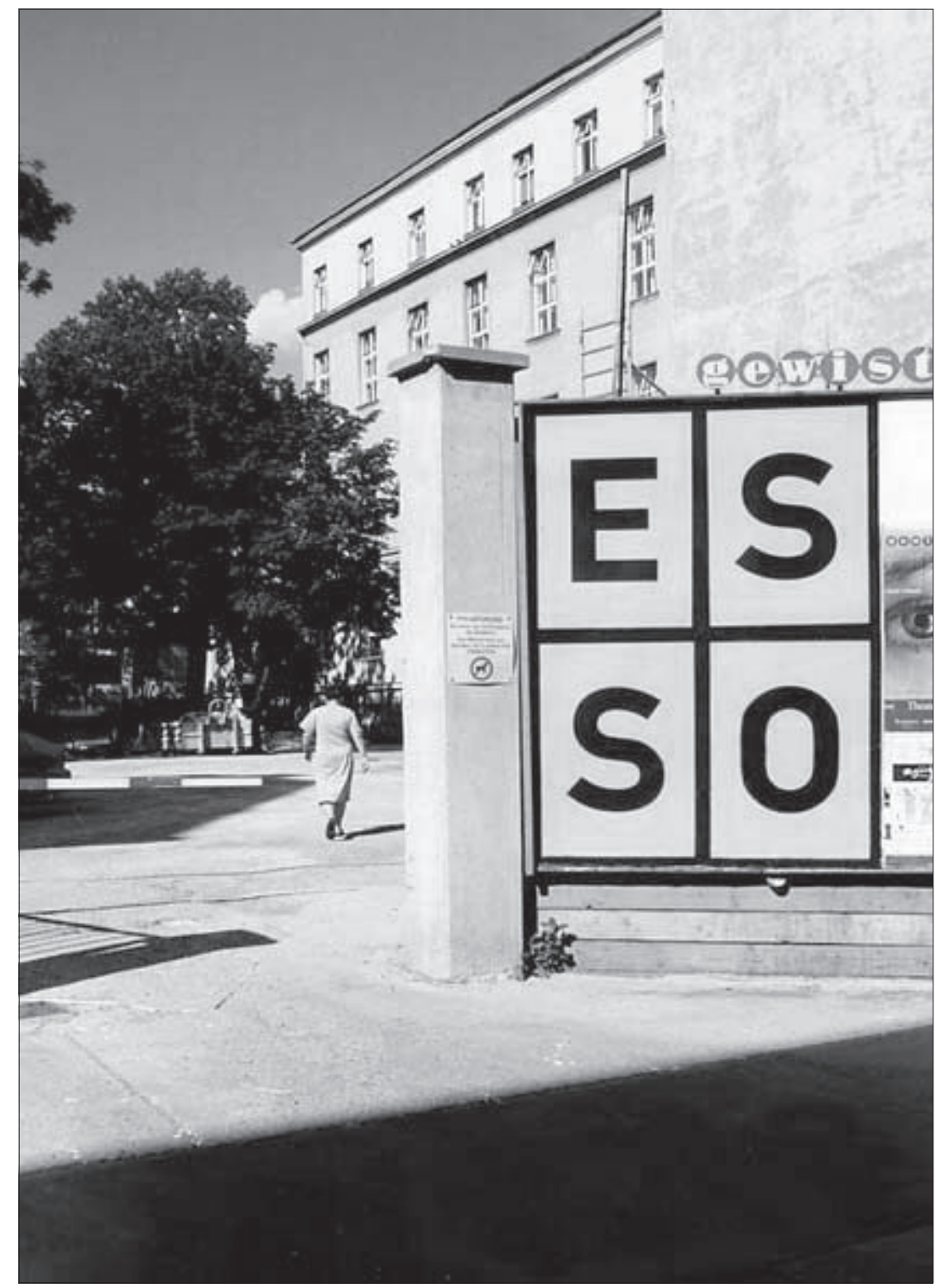

1. Monolog des Vertrauens (Photograph by Otto Mittmannsgruber) 
In these two projects the two primary objectives of advertising were deconstructed visually and rhetorically: to create a unique brand/product identity and to create a unique desire that only the company's products can satisfy. It is important to note, however, that it was up to the viewer to figure out what was going on and what it might mean. At the time when "Monolog des Vertrauens" and "Shokomonolog" were posted on billboards, there were neither any explanatory texts nor any suggestions that there were artists at work. The only paratextual indices of art consisted in newspaper articles and art reviews. ${ }^{10}$ The responses from ordinary people were divers and also varied between different projects. Some campaigns ("13 tote Österreicher", "Fremd", "52 Zitate") provoked strong reactions both in media and directly from people. ${ }^{11}$ Other strong reactions came from advertising agencies who felt ignored or viewed the artists as competitors - some large advertising companies even warned their clients against taking part in art projects. ${ }^{12}$

In order to understand the cultural meanings of these interventions in commericalized public space, it is illuminating to compare them with advertising that violates the unwritten laws of marketing. The traditional (and still predominant) form of advertising focuses on selling products and brand names. Whereas companies have always tried to associate their products with certain lifestyles, it is only recently that the central focus is on selling lifestyles and not products (Berger 2001: 148-161; Klein 2000: 27-61). If this marketing strategy is a heresy of sort, then what of an advertisement that makes ironical comments on itself as advertising? A striking example is the commercial for the soft drink Sprite with the slogan "Image is nothing. Obey your thirst." Although this kind of self-conscious and self-ironic advertising hardly will become a very strong trend in marketing, it is popular among companies trying to reach alternative and media conscious youth groups (Berger 2001: 167-181). There are even companies that flirt with anti-advertising movements engaging in cultural jamming or ad-busting (Berger 2001: 448-461). As examples of the latter can be mentioned advertisements for Reactor jeans (1997) and Captain Morgan Rum (2000), which both appropriate the visual language of ad-busting (Berger 2001: 458-459).

In this context, one can read Mittmannsgruber and Strauß's interventions as artistic and playful expressions of cultural jamming, but on a fairly large scale. However, as these advertising campaigns never ceased being commercial advertisements, it is not obvious to call them art, or even sponsored art. But then what are they? In a time when film directors like Woody Allen and Spike Lee make television commercials and poets write copy for advertising, it is not strange if visual artists work with advertising as a material for their art. The advertisements for Absolut vodka are well known examples, as are Graham Sutherland's advertisements for Shell (Walker 2001: 59). Other prominent examples of mixing art and advertisements are Andy Warhol's detergent boxes and prints of Campbell's canned soup, and inversely the appearance of artworks of Roy Lichtenstein, Frank Stella, and Alexander Calder in advertisements (Walker 2001: 61). When Mittmannsgruber and Strauß's projects were shown at the Museum für angewandte Kunst (MAK) in Vienna in 2004, it would seem that the art world had given it its blessing. But rather than settling the issue, it raises more questions than it answers. ${ }^{13}$ For instance, does the exhibition of their work in a museum for applied arts really qualify the work as art? And how does it articulate the relation between art institutions and the market place? ${ }^{14}$ Perhaps the question if it is art is misplaced, perhaps it is better to ask what it means to call these interventions art.

Another project by Mittmannsgruber and Strauß, with the title "Ich" (I), focused on a different aspect of advertising rhetoric, the address or interpellation (Mittmannsgruber 
\& Strauß 2004: 84-93). The project was carried out with 800 posters and 10 different subjects in Vienna in 2002. By writing (or rather tearing out) the word "Ich" on advertising posters for mineral water (Römerquelle), underwear (Palmers) and wireless communications (WIFI), Mittmannsgruber and Strauß make explicit the unexpressed interpellation of the "self" ("Ich") as primary subject and object of consumption. Although traditional advertising focuses on selling products, the way it communicates with the public is by associating products with fantasies that can be "realized" by consumption. Hereby public advertising becomes a projection space for individual (and private) phantasmagoria. By consuming I become happy, by identifying myself with the stereotypes in advertising I become an object of consumption.

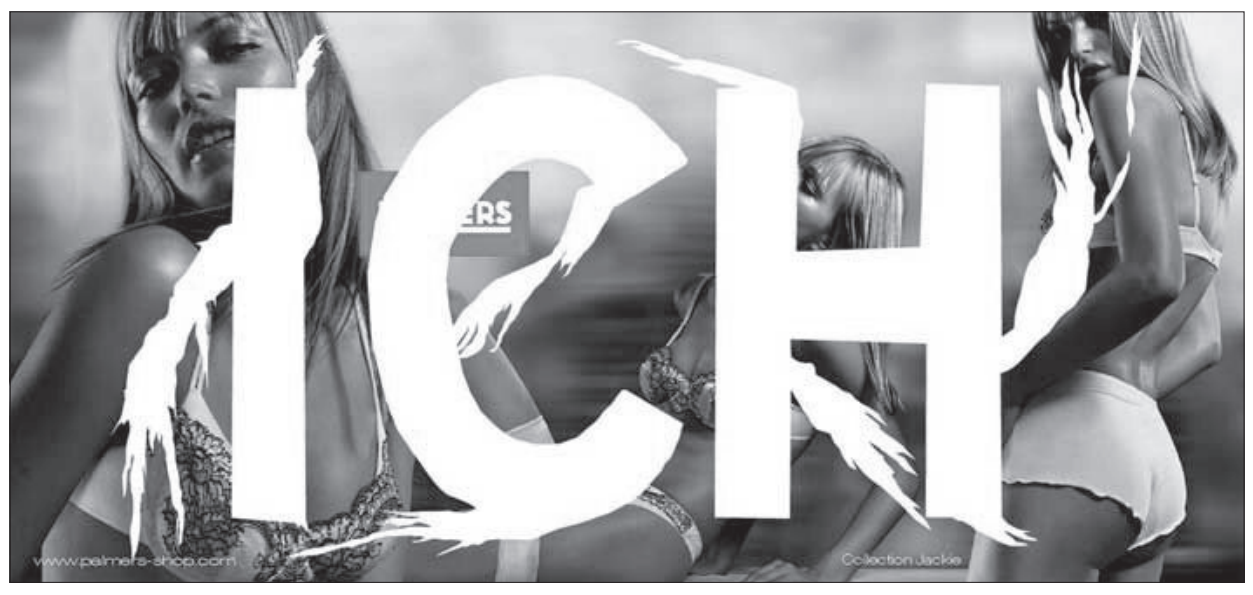

2. Ich (Photograph by Otto Mittmannsgruber)

As in all forms of mass media communication, advertising must create and maintain contact with the audience (phatic communication), which it can do in various ways in different contexts. In advertising, the preferred way to achieve this objective is by finding a means to speak directly to our dreams of who we want to be. Hence "successful copywriting depends upon insight into people's minds: not individual minds [...] but into the way the average people think and act" (Gilbert Russell, quoted in Leavis 1930: 11). The talent to connect to our deepest feelings is worth millions in the advertising industry. Not only can good advertising in fact "explain us to ourselves," 15 but according to Marshall McLuhan the advertising of our time constitutes "the richest and most faithful daily reflections that any society ever made of its entire range of activities." (McLuhan 1964: 232) If the aim of all advertising is to sell (products or services) and to turn the audience into buyers and consumers, preferably without being made aware of it, the overarching ideology of advertising consists of an interpellation of the audience as consumers. This project ("Ich") constituted a rhetorical analysis of the communicative situation of the advertising text.

If in the first two mentioned projects, "Monolog des Vertrauens" and "Shokomono$\log$ ", the rhetorical analysis of the advertising monologue makes use of estrangement as aesthetic device, in "Ich" it makes explicit the communicative interpellation in advertising. In a sense, this intervention is more openly critical of advertising, but perhaps also more difficult to grasp for the viewer. It should not be obvious to the passer-by what 
the word "Ich" signifies in the advertisement. The way the word "Ich" is torn out from the poster also gives associations to ad-busting, although for the uninitiated it would be impossible to discern whether it is authentic or not.

This ironic and critical device becomes even more striking in the project called "Fremd" (Stranger) (Mittmannsgruber \& Strauß 2004: 44-49). It was carried out in southern Austria in the year 1997 with 200 posters and a single subject. The image seems to represent a crumpled kitchen towel over which is put the text "Wir bleiben unter uns" (We stay among ourselves). In the bottom right corner, where the trade mark or logotype normally are placed in advertising posters, there is a slanted banner with the text "1996 konnten wir 92 Prozent aller Asylanträge ablehnen!" (In 1996 we could reject $92 \%$ of all asylum applicants!). The poster was conceived on the occasion when the European Union had proclaimed 1997 a "Year against racism, anti-semitism and xenophobia" and Austria the previous year had ranked last among the European countries that had accepted refugees (Mittmannsgruber \& Strauß 2004: 46). One can interpret the crumpled kitchen towel in different ways, but undisputably Mittmannsgruber and Strauß have opened the advertising monologue not only towards an ironic discourse, but also to an expressedly political one.

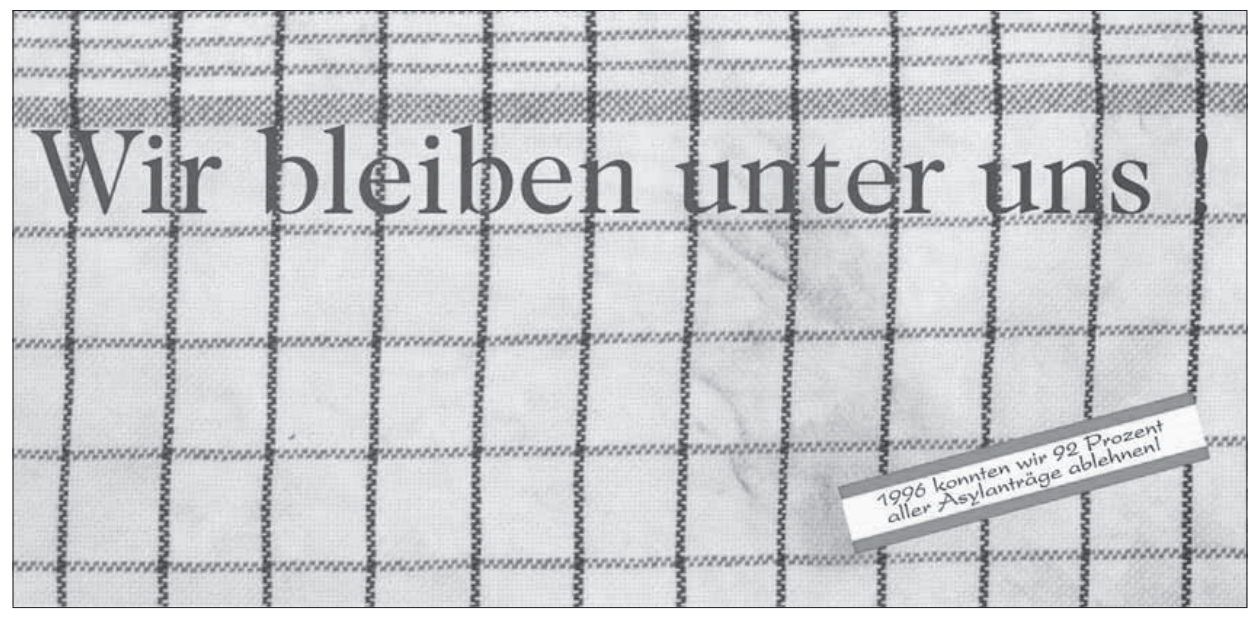

3. Fremd (Photograph by Otto Mittmannsgruber)

At this point one has to address the difficult question of politics and art, and what makes art political. This question means something quite different today than it did in the $1960 \mathrm{~s}$ and 1970s. When the magazine Artforum in 2004 made a special issue on art and politics, it was obvious that the critics were quite uncomfortable with the juxtaposition of the two terms. At the same time, however, they could not fail to notice that the contemporary art scene is becoming increasingly political. And it is not just a question of individual artists, political art seems in fact fashionable, as can be seen from the last two Documentas (1997 and 2001) and Venice Biennali (2003 and 2005), and the 2004 Whitney Biennial (Griffin 2004: 205; Danto 2004).

One way of answering the question of what makes art political is to say that all art is political, although primarily in a conservative or reactionary way by affirming existing traditions and art forms, as well as institutional and social structures in which art is exhibited and produced. A more discriminating view of political art is expressed by 
Andrea Fraser, who defines it as "art that consciously sets out to intervene in (and not just reflect on) relations of power, and this necessarily means on relations of power in which it exists." (Fraser quoted in Bordowitz 2004: 215) According to Fraser, the intervention must be the "organizing principle of the work in all its aspects", not only in its form and content, but also in the mode of production and circulation. On these conditions, I think it would be safe to say that surrealism was a political art movement (and part of dadaism also); and that the works of John Heartfield, Victor Burgin, Jenny Holzer, and Barbara Kruger are political in a strong sense (Walker 2001: 107-108, 124). Nevertheless, even though the works of these artists are radically political, that does not prevent the art as system from recuperating them and transforming them into a "form of capital within art discourse." (Fraser quoted in Bordowitz 2004: 215) It would seem that Mittmannsgruber and Strauß's artistic interventions in commercialized public space also would qualify as political in this strong sense, yet it is uncertain what kind of value or currency they will have in the art world.

In this context one could also mention another strand in marketing: advertising with a social agenda. This form of advertising comes in two forms: public authorities or nonprofit organisations that want to inform the public on certain matters (such as the dangers of smoking, of drug abuse, of driving drunk, of pollution, etc.); and companies who want to be associated with good causes (such as equality for women, stopping child abuse) (Berger 2001: 292-325). A rather extreme example of the latter are Oliviero Toscani's advertisements for Benetton, though one can sometimes debate whether the "causes" here are not sensational rather than good (Berger 2001: 249, 250-251; Walker 2001: 159f).

Mittmannsgruber and Strauß's artistic interventions are aimed directly at questions of power and of public discourse, and they enact a questioning of one-way mass media communication and a politicizing of commercialized public space. Who gives and who takes the right to use public spaces as an arena for public address? And cannot the public demand the right to use this physical mass medium in order to participate in public discourse? One way of articulating these questions is by writing them down on advertising posters. In the project "Karusell", which was carried out both on billboards and in newspapers, exactly these kinds of questions were asked, accompanied by a thick arrow pointing either at an adjacent advertising poster or newspaper article. ${ }^{16}$ In this way, the viewer or reader was addressed not as a passive audience, but as participant in public discourse. This interpellation of the viewer constitutes a rhetorical figure Jean-François Lyotard has called "metalepsis of the partner" (métalepse du partenaire), through which the (passive) spectator is implicated in the position of (active) partner in a dialogue

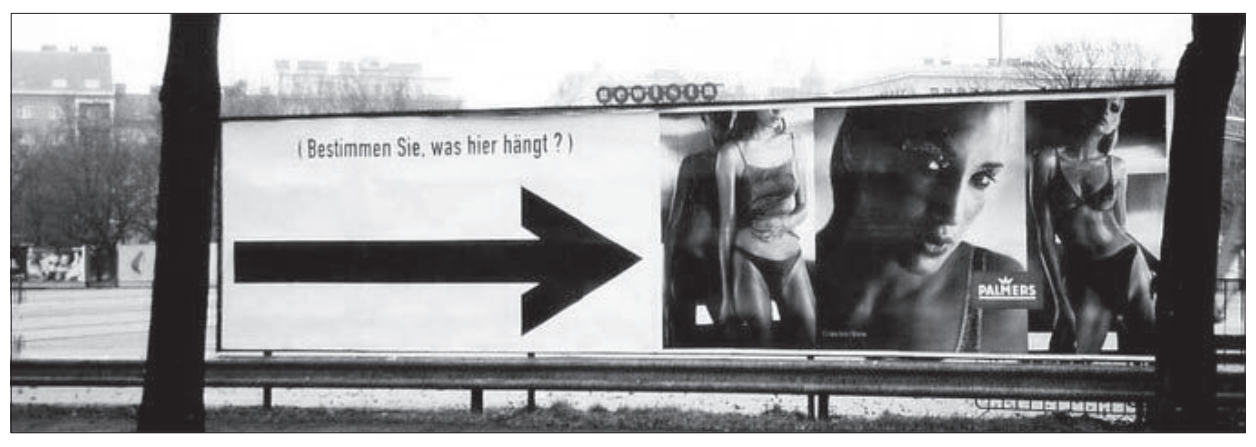

4. Karusell (Photograph by Otto Mittmannsgruber) 
(Lyotard 1983: 47). However, the questions are not only directed towards the primary viewer, but are also about others, for example how children are affected by advertising. In this way Mittmannsgruber and Strauß reframe the advertising monologue in the form of a conversation; one may say that it has been "dialogized" (Bakhtin 1981). The advertising monologue is broken against other discourses and can no longer remain unquestioned, unopposed. Likewise, in the images that document the interventions as communicative situations, the simultaneously open and closed nature of public discourse in commercialized mass media is made strikingly clear. As viewer of these images one is caught by a movement that simultaneously opens the advertising monologue and reveals its closed nature.

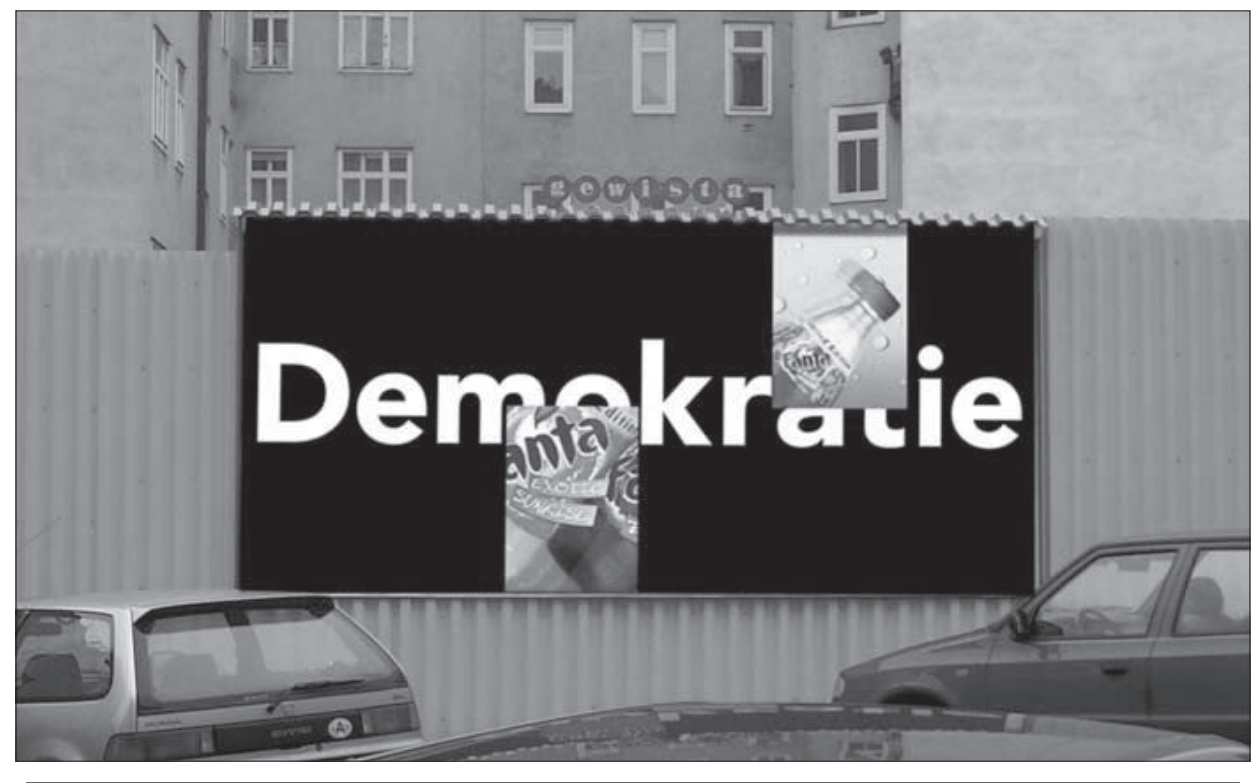

5. Demokratie (Photograph by Otto Mittmannsgruber)

As a final example of Mittmannsgruber and Strauß's artistic explorations of mediated communication in public spaces, I will take the project "Demokratie" (Democracy), carried out in Vienna in 2000 with 800 posters and 20 different subjects, also executed in newspapers and local radio stations (Mittmannsgruber \& Strauß 2004: 74-83). The posters were monochrome black with the word "Demokratie" printed in large, white letters. In the posters were also inserted two sections of other advertisement posters, these being put in the "right" position according to the original. One of the sections was always the one that showed the brand logo, or part of it. In the newspapers, the advertisement consisted only of the word "Demokratie", but to the word was added the symbol ${ }^{\circledR}$, the sign used to indicate registered trademark. One may read this as critique that commercial forces have taken over the public discourse in modern democracies, that there is not enough space for citizens to make themselves heard in the public sphere; and also as a critique of Coca-Cola-Democracy where people are happy as long as they may satisfy their artificial desires. The version of the project that was published in newspapers suggests that democracy may be represented as much as a trademark as a product. And what does that mean? 
As mentioned above, several of Mittmannsgruber and Strauß's interventions in commercialized public spaces were done in cooperation with the companies whose products and trademarks were advertised. How does this affect the meaning and artistic integrity of the projects? By presenting advertising as art, this gives an aesthetic value to advertising (and to the products). This is in line with the increased prestige that advertising has received in the last decades, both culturally and aesthetically. But are we to perceive Mittmannsgruber and Strauß's "artistic" practice as allied with this tendency or as a critical commentary of it? Or both?

Another aspect of their project constitutes an investigation of the various roles for art in commercialized mass media, for art as a mass media, and for media art as public art. What is the role of art in society and outside the museum and exclusive art collections? What happens with art when it ventures into the public sphere, and what happens with the public sphere when art enters? In order to answer these questions we will have to return to the different figurative public spaces in contemporary society.

\section{Conclusion}

As stated in the introduction I make no claim to say anything substantially new about the public sphere, public space, public spaces or public discourse. However, in studying the interventions by Mittmannsgruber and Strauß in commercialized public space, it has become clear exactly how closed this discourse is, both in terms of not being open to the public and in being confined to a persuasion and marketing rhetoric. Although commercialized public space is only a limited part of a general public space, albeit a quite substantial part, one may still view it as a figure of the public sphere. In this respect it shows a striking resemblance to the representative liberal theory of the public sphere. The ordinary citizens are not welcome to participate, the larger (commercial) players get proportionally more media space, and the role of the public is to choose among the products.

As a figure of the public sphere, commercialized public space also shows some resemblance to the view of the public sphere as an agonistic arena where the actors (companies) can fight for and earn public recognition. That is exactly what companies strive for when they market their brands and products. Mittmannsgruber and Strauß's rhetorical analysis is quite effective in showing this. However, as the citizens (consumers) largely are excluded from participating, the resemblance with Arendt's model of the public sphere is in fact rather weak.

In the discursive view of public space, commercialized public space is a direct negation of public dialogue and deliberation. However, when Mittmannsgruber and Strauß open up the advertising monologue for other voices and turn it, through metalepsis of the partner, into a conversation, then it would appear to look in the direction of public dialogue and deliberation. The same could in fact be said about their extensive use of irony, which aims at provoking thought and critical reflection in the public body. But again, it is a far way to go for commercialized public space to come anywhere close to Habermas' ideal of the public sphere.

As for the view of the public sphere as being (ideally) multiple and not closed to the private realm, Mittmannsgruber and Strauß's analysis of the rhetorical interpellation of the consumer in "Ich" reveals that advertising operates on private fantasies, and hence (always) already has dissolved the distinction between private and public. We had just not noticed it before. As regards plurality of public spheres, one can argue that the 
project "Demokratie" revealed that commercialized public space can be constituted as a part of the political public sphere. In the words of Arendt, already quoted above, one can say that "it is potentially there, but only potentially, not necessarily and not forever." By their example, Mittmannsgruber and Strauß show that commercialized public space can be reclaimed for other purposes, other functions, and in this way be opened to the public.

\section{Notes}

1. An extensive bibliography on the notion of the public sphere is found in Strum 1994.

2. Rilke, "Die Achte Elegie": "Mit allen Augen sieht die Kreatur / das Offene. Nur unsre Augen sind / wie umgekehrt und ganz um sie gestellt / als fallen, rings um ihren freien Ausgang. / Was draußen ist, wir wissens aus des Tiers / Anlitz allein; denn schon das frühe Kind / wenden wir um und zwingens, daß er rückwärts / Gestaltung sehe, nicht das Offne, das / im Tiergesicht si tief ist. Frei von Tod. / [...]"

3. Arendt also writes: "the reality of the public realm relies on the simultaneous presence of innumerable perspectives and aspects in which the common world presents itself and for which no common measurement or denominator can ever be devised. For though the common world is the common meeting ground for all, those who are present have different locations in it, and the location of one can no more coincide with the location of another than the location of two objects. Being seen and being heard by others derive their significance from the fact that everybody sees and hears from a different position. This is the meaning of public life." (Arendt 1958: 57)

4. In fact, already Hannah Arendt noted that, "[h]istorically, the last public realm, the last meeting place which is at least connected with the activity of homo faber, is the exchange on which his products are displayed." (Arendt 1958: 162)

5. For fuller treatment of the subject, see Presbrey 1929; Houck (ed.) 1969; Lears 1994.

6. For an influential discussion of how television affected the public sphere, see e.g. Meyrowitz 1985: 73-125. For discussion of how the Internet may transform the public sphere, see e.g. Poster 1995; Slevin 2000: 185-197; Papacharissi 2002.

7. "The public space, the private sector space, and the personal spaces merge seamlessly." (Camp \& Chien 2000: 14)

8. This should not be confused with what Habermas calls representative public sphere (Habermas 1962: 7). The advertising monologue that goes on in public places does not only try to persuade us to act in certain ways; it speaks to us not as citizens (or as subjects) but as consumers.

9. The projects are also documented on the website http://www.kunstundmedien.org/htm/mono.htm.

10. See NV 1995a; NV 1995b; K.W. 1995; Schlocker 1995; "Verkehrte Werbewelt" 1995; PRA 1996; NV 1997; "Anti-Logo" 1999; C. P. 1999; "Plakatkunst im öffentlichen Raum" 1999; Vogel 1999; Ullrich 2001; Vogel 2001; Mittringe 2002.

11. Otto Mittmannsgruber, personal correspondence to author by email, October 5, 2005.

12. Otto Mittmannsgruber, personal correspondence to author by email, October 5, 2005.

13. For a critical discussion of the notion of the art world, see Dahlberg 2001.

14. A striking illustration of this question is the growing importance of merchandising in art museums. It is not uncommon that the visitor has to pass through the museum shop in order to come to the collections (Leong 2001: 144-153).

15. This is a comment made about the legendary American advertising creator Bill Bernbach. Quoted in Berger 2001: 39 .

16. The project was carried out in Vienna in 2002 with 1000 posters and 5 different subjects in combination with 20 different advertising posters. The newspaper project appeared in Die Standard, 16-22 January 1999 (Mittmannsgruber \& Strauß 2004: 50-61).

\section{References}

"Anti-Logo". Profil (Nr. 29) July 17, 1999.

Arendt, Hannah (1950) The Origins of Totalitarianism. San Diego: Harcourt, n.d.

Arendt, Hannah (1958) The Human Condition (1958), 2nd ed. Chicago: Univ. of Chicago Press, 1998.

Bakhtin, Mikhail M. (1981) "Discourse in the Novel", in M. Holquist (ed.) The Dialogic Imagination. Austin: Univ. Texas Press, pp. 259-422. 
Benhabib, Seyla (1992) "Models of Public Space", in C. Calhoun (ed.), Habermas and the Public Sphere. Cambridge: The MIT Press, pp. 73-98.

Berger, Warren (2001) Advertising Today. London: Phaidon.

Boggs, Carl (1997) 'The Great Retreat: The Decline of the Public Sphere in Late Twentieth-Century America", Theory and Society 26 (1997), pp. 741-780

Bordowitz, Gregg (2004) "Tactics Inside and Out”, Artforum, September 2004, pp. 212-215, 292.

Burke, Edmund (1790) Reflections on the Revolution in France (1790), ed. L.G. Mitchell. New York: Oxford U.P. 1993

C. P. (1999) "Werben mit Kunst oder Kunst als Werbung”. Süddeutsche Zeitung, December 1999.

Camp, Jean, \& Chien, Y.T. (2000) "The Internet as Public Space. Concepts, Issues, and Implications in Public Policy", Computers and Society (September 2000), pp. 13-19.

Carey, J. (1995) "The Press, Public Opinion, and Public Discourse", in T. Glasser \& C. Salmon (eds.) Public Opinion and the Communication of Public Consent. New York: Guilford, pp. 373-402.

Castells, Manuel (2001) The Rise of the Network Society, $2^{\text {nd }}$ ed. Oxford: Blackwell.

Chung, Chuicha Judy (2001) "Ms. Consumer. The Making of Public Space", in C.J. Chung (ed.) et al.: Harvard Design School Guide to Shopping. Project on the City 2, Köln: Taschen, 2001, pp. 505-525.

Dahlberg, Leif (2001) "Den estetiska relationen", Res Publica 53 (2001), pp. 133-140.

Dahlberg, Lincoln (2005) "The Habermas Public Sphere: Taking Difference Seriously?", Theory and Society 34 (2005), pp. 111-136.

Danesi, Marcel (2002) Understanding Media Semiotics. London: Arnold

Danto, Arthur C. (2004) "American Self-Consciousness in Politics and Art", Artforum, September 2004, pp. 206-209.

Downs, Anthony (1957) An Economic Theory of Democracy. New York: Harper \& Row.

Foucault, Michel (2001) "La 'gouvernementalité'”, in D. Defert \& F. Ewald (eds.) Dits et écrits II, 19761988. Paris: Gallimard, pp. 635-656.

Foucault, Michel (2000) "The Subject and Power", in J.D. Faubion (ed.) Power (Essential Works of Michel Foucault 1954-1984, Vol. 3) New York: The New Press, 2000, pp. 326-348.

Foucault, Michel (1997) "Technologies of the Self", in P. Rabinow (ed.) Ethics. Subjectivity and Truth (Essential Works of Michel Foucault 1954-1984, Vol. 1), New York: The New Press, pp. 223-251.

Fraser, Nancy (1992) "Rethinking the Public Sphere: A Contribution to the Critique of Actually Existing Democracy", in C. Calhoun (ed.), Habermas and the Public Sphere. Cambridge: The MIT Press, pp. 109-142.

Gennep, Arnold van (1909) Les Rites de passage. Étude systématique des rites. Paris: Librairie critique Émile Nourry.

Griffin, Tim (2004) "The Art of Politics", Artforum, September 2004, p. 205.

Gunter, Jutiki, with Inaba, Jeffrey (2001) "Nikevolution. Strategies of Brand”, in C.J. Chung (ed.) et al.: Harvard Design School Guide to Shopping. Project on the City 2, Köln: Taschen, pp. 542-557.

Habermas, Jürgen (1962) The Structural Transformation of the Public Sphere. An Inquiry into a Category of Bourgeois Society (1962), trans. T. Burger. Cambridge: The MIT Press, (1989) 1991.

Habermas, Jürgen (1996) Between Facts and Norms. Contributions to a Discourse Theory of Law and Democracy, trans. W. Rehg. Cambridge: The MIT Press.

Houck, J.W. (Ed.) (1969) Outdoor Advertising. History and Regulation. Notre Dame: University of Notre Dame Press.

K.W. (1995) "Nackte Namen”, Wiener Zeitung, July 18, 1995.

Klein, Naomi (2000) No Logo. London: Flamingo.

Kornhauser, William (1960) The Politics of Mass Society. London: Routledge \& Kegan Paul.

Lears, Jackson (1994) Fables of Abundance. A Cultural History of Advertising in America. New York: Basic Books.

Leavis, Frank Raymond (1930) Mass Civilisation and Minority Culture. Cambridge: Minority Press.

Leong, Sze Tsung (2001) "... And Then There Was Shopping. The Last Remaining Form of Public Life", in C.J. Chung et al. (ed.) Harvard Design School Guide to Shopping. Project on the City 2. Köln: Taschen, pp. 129-155.

Lyotard, Jean-François (1983) Le Différend. Paris: Minuit.

McLuhan, Marshall (1964) Understanding Media. The Extensions of Man. Cambridge: The MIT Press, 1999.

Meyrowitz, Joshua (1985) No Sense of Place. The Impact of Electronic Media on Social Behavior. Oxford: Oxford U.P.

Mill, John Stuart (1861) Considerations on Representative Government. Amherst: Prometheus Books, 1991. 
Mittmannsgruber, Otto, \& Strauß, Martin (2004) Kampagnen ohne Auftrag. Kunstprojekte in Massenmedien 1995-2004, hrsg. P. Noever. Vienna: MAK.

Mittringe, Markus (2002) "Ein Zeigefinger wie ein Holzhammer. 700 manipulierte Großplakate wider die gängigen Lügen der Werbung”. Der Standard, January 11, 2002.

NV (1995a) "Veranstaltungen - Ausstellunge...". Die Presse, July 17.

NV (1995b) "Ausgestellt in Wienvon Johann...". Die Presse, August 25.

NV (1997) "800 Großplakate erinnern in...". Die Presse, July 21.

PRA (1996) “1000 'Testbilder' sorgen für scharfe Ansichten in der Stadt. Plakataktion als Kooperation von Kunst und Kommerz”. Kurier (Vienna), August.

Papacharissi, Zizi (2002) "The Virtual Sphere. The Internet as a Public Sphere”, New Media \& Society, Vol. 4, No. 1 (2002), pp. 9-27.

"Plakatkunst im öffentlichen Raum". NBK Aktuell (Berlin), March 1999.

Poster, Mark (1995) "CyberDemocracy: Internet and the Public Sphere". http://www.hnet.uci.edu/mposter/ writings/democ.html

Presbrey, Frank (1929) The History and Development of Advertising. Westport: Greenwood, 1968.

Proposition 1997/98:136. "Statlig förvaltning i medborgarnas tjänst". http://www.regeringen.se/content/1/ c4/36/68/ed586c4f.pdf; and http://www.24-timmarsmyndigheten.se

Rilke, Rainer Maria (1991) Duineser Elegien, in Werke in drei Bänden, Bd. 1. Frankfurt a. M.: Insel Verl.

Schlocker, Edith (1995) "Die Vielfalt liegt diesmal in der Einheitlichkeit". Tiroler Tageszeitung, July 8, 1995.

Schudson, Michael (1997) "Why Conversation is Not the Soul of Democracy", Critical Studies in Mass Communication, Vol 14, No. 4 (1997), pp. 1-13.

Schumpeter, Joseph (1942) Capitalism, Socialism, Democracy. New York: Harper.

Slevin, James (2000) The Internet and Society. Cambridge: Polity Press.

Smith, Dorothy E. (1999) Writing the Social: Critique, Theory and Investigations. Toronto: Univ. of Toronto Press.

Strum, Arthur (1994) "A Bibliography of the Concept Öffentlichkeit", New German Critique 61 (Winter 1994), pp. 161-202.

Thompson, E.P. (1968) The Making of the English Working Class. Harmondsworth: Penguin.

Thompson, John B. (1995) The Media and Modernity. A Social Theory of the Media. Cambridge: Polity Press, 2000.

Ullrich, Wolfgang (2001) "Medienprojekte auf Plakaten, im Radio, im Info-Point, in Tageszeitungen und Magazinen". Springerin Online, 1/2001.

Ullrich, Wolfgang (2004) "Supermarke 'Kunst"”, in Mittmannsgruber \& Strauß (2004), pp. 124-130.

"Verkehrte Werbewelt. Die Plakat-Kunst-Aktion „Monolog des Vertrauens“". Oberösterreichische Nachrichten, July 8, 1995.

Vogel, Sabine B. (1999) "Keine Werbung. Eine Städte-Kampagne: Plakate, die Fragen stellen". Frankfurter Allgemeine Zeitung, February.

Vogel, Sabine B. (2001) "Various locations: 'Demokratie®' - Reviews - Otto Mittmannsgruber and Martin Strauß, Vienna". Artforum, Summer.

Walker, John A. (2001) Art in the Age of Mass Media, $3^{\text {rd }}$ ed. London: Pluto Press. 